\title{
Stretnutie s Vierou Gašparíkovou - oslava prácou
}

\author{
Zuzana Beňušková (Nitra)
}

Aj ked' vek žien sa údajne nepatrí uvádzat', existujú situácie, ked' sa to človeku s obdivom žiada urobit. Naša kolegyňa, dlhoročná pracovníčka Ústavu etnológie SAV v Bratislave, PhDr. Viera Gašparíková, CSc. sa 15. 4. 2018 dožila svojich 90. narodenín. Devätdesiatku oslávila pracovným seminárom, do ktorého sa aktívne zapojila prednesením vlastného originálneho príspevku.

Viera Gašparíková patrí k popredným osobnostiam slovenskej aj európskej folkloristiky. Takmer celý profesionálny život prežila v Ústave etnológie SAV, kde sa zameriavala na výskum ludovej prózy. Oslovili ju predovšetkým zbojnícke povesti a rozprávky. Svoje zbery rozprávok uzavrela trilógiou Slovenské l'udové rozprávky (1993-2004), ktorej zrod sprevádzali v dobách minulých rôzne ideologické problémy a po roku 1989 roky hl’adania úspešných stratégií pre realizáciu tohto vel'kého projektu.

Stretnutie s Vierou Gašparíkovou pri príležitosti jej jubilea sa konalo 25. 5. 2018 v pomerne komornom, ale pestrom zložení účastníkov. V to ráno bol v Bratislave priam tropický lejak, ale napriek nevlúdnemu počasiu sa $\mathrm{v}$ tanečnej sále v sídle štátneho umeleckého súboru SLUK v Rusovciach - pravobrežnej časti Bratislavy stretli slovenskí a českí folkloristi a folkloristky, aby ju na niekol'ko hodín zaplnili rozprávaním o rozprávkach. Jubilantku uviedla a celé podujatie moderovala jeho hlavná organizátorka Hana Hlôšková. Skôr než začal samotný pracovný seminár, odzneli zdravice zástupcov gratulujúcich inštitúcií a piesňový darček $\mathrm{v}$ podobe balady v interpretácii Margity Jágerovej z Katedry etnológie a folkloristiky FF UKF v Nitre, kde len nedávno jubilantka úspešne vyškolila svoju doktorandku.

Príspevky, ktoré na pracovnom seminári odzneli, súviseli s folkloristickým a jazykoved- ným zberom rozprávok v Európe v rôznych časových obdobiach - od 19. storočia až do súčasnosti - a s povestami o zbojníkoch. Do staršej minulosti siahla Janka Pácalová z Ústavu slovenskej literatúry SAV na príklade analýzy rozprávok Samuela Reussa a Renáta Bojničanová z Katedry románskych jazykov a literatúry PF UK v Bratislave v príspevku o európskych kontextoch zbojníckych povestí. Ďalšia séria príspevkov pripomenula terénne výskumy prednášajúcich. Na dlhoročnú spoluprácu s Vierou Gašparíkovou si zaspomínala jej súputníčka z moravskej strany hranice Marta Šrámková z Etnologického ústavu AV ČR v Brne v príspevku Společné putováni za folklorem na moravsko-slovenském pomezi. Na viaceré časové línie výskumu v troch generáciách folkloristov na Kysuciach upozornila Gabriela Kiliánová z Ústavu etnológie SAV. Jana Pospísilová z Etnologického ústavu AV ČR v Brne vážne aj vtipne priblížila svoje výskumy rozprávaní detí na Morave v príspevku Výskumy tradičnej prózy - Nedašovské závrší. Priam detektívny príbeh o hladaní aj nájdení záznamov rozprávok študentov Franka Wollmana z tzv. moravských zberov vyrozprávala Anna Zelenková zo Slovanského ústavu AV ČR v Prahe. Tento príspevok bol mimoriadnym osviežením podujatia. Zdalo by sa, že všetky zásuvky histórie sú už prebádané a zrazu sa podarilo vypátrat zbierky, o ktorých sa dovtedy predpokladalo, že boli zničené. Takto sa wollmanovský archív rozprávok zozbieraných v prvorepublikovom Československu obohatil o staronový originálny materiál.

Pozoruhodný bol aj príspevok samotnej jubilantky, ktorá už pred seminárom priznala, že ho musela výrazne skrátit, aby sa zmestila do vymedzeného časového limitu. A poslucháči by ju vydržali počúvat aj dlhšie, pretože rozprávala o svojich skúsenostiach zo zahraničných stretnutí 
folkloristov - zberatelov rozprávok a o pozícii slovenských rozprávok v širšom európskom kontexte. Je v pláne príspevky z podujatia vydat.

Oslávenkyňu prišli pozdravit aj dlhoroční spolupracovníci a priatelia doktorky Gašparíkovej, ako napríklad Lubica Droppová a Viliam Gruska. Profilový videodokument o Viere Gašparíkovej je možné si pozriet na youtube.com, v cykle Osobnosti slovenskej etnológie.

$\mathrm{Na}$ tomto doslova rozprávkovom podujatí spolupracovali viaceré inštitúcie - Národopis- ná spoločnost̉ Slovenska, Ústav etnológie SAV, Katedra etnológie a muzeológie FiF UK v Bratislave, Centrum pre tradičnú ludovú kultúru a SLUK. Všetkým, ktorí prispeli k tomuto vydarenému podujatiu, patrí vd’aka a oslávenkyni obdiv a úcta za celoživotnú prácu, ale aj za vitalitu, ktorá ju stále radí k tvorivým pracovníkom na poli folkloristiky. Pani doktorke Gašparíkovej prajeme, aby jej zdravie a radosṫ z tvorivých aktivít vydržalo aj do d’alších rokov jej bohatého života zasväteného práci.

Prof. PhDr. Zuzana Beňušková, CSc.

Katedra etnológie a folkloristiky

Filozofická fakulta, Univerzita Konštantína Filozofa

Hodžova 1, 94974 Nitra, Slovensko

zbenuskova@ukf.sk 